\title{
Internet, Trust in Government, and Citizen Compliance
}

\author{
Tobin Im*t, Wonhyuk Cho*, Greg Porumbescu ${ }^{\ddagger}$, Jungho Park ${ }^{\S}$ \\ *Seoul National University; ${ }^{+}$George Mason University; ${ }^{\ddagger}$ Myongji University; \\ sUniversity of Pittsburgh
}

\section{ABSTRACT}

\begin{abstract}
This research investigates how levels of citizen trust in government and compliance are affected by citizens' use of the Internet. Starting from the premise that information is a key determinant of public opinion and citizen behavior, this research explores the extent to which the time that citizens spend on the Internet affects their trust in government and compliance with government policies, compared with the influence of the traditional, offline, mass media modalities, such as newspapers. In addition, we also assess the impact of citizens' use of e-government on levels of trust in government and compliance. The results of the analyses suggest that the more time individuals spend on the Internet, the lower their degree of trust in government and lower level of citizen compliance. However, our results also suggest that such negative effects of the Internet can be moderated through citizens' increased use of e-government.
\end{abstract}

\section{INTRODUCTION}

The past several decades have witnessed a continual erosion of public trust in government (Abramson and Inglehart 1995; Dalton 2002; Nevitte 2002), with changes in the media environment contributing to the reshaping of the citizen-state relations (Gordon 2000). Forced to adapt to the decline in public trust, a situation that is said to cause a climate of "political malaise" (Hetherington 1998; Welch, Hinnant, and Jae Moon 2005), governments' efforts to satisfy the public's demands and expectations are now likely to be met with skepticism or worse (cf. Luhman 2000). Because increased levels of government mistrust lead to challenges related to government legitimacy, national competitiveness, and public compliance with government policies, there is a clear need to address this issue (Braithwaite and Makkai 1994; Gamson 1968; Lee 2003; Kim 2010; Muller, Jukam, and Seligson 1982; Nye 1997).

Factors that can influence public trust include various elements of the sociopolitical atmosphere, such as media, economic climate, participatory culture, and public

\footnotetext{
A previous version of this paper was presented at the 2010 European Group for Public Administration's annual conference in Toulouse, France (September 7-10) in the PSG1: e-government and ICT in PA session. The authors would like extend their sincere thanks to Hyunkuk Lee and the three anonymous reviewers for their help throughout the course of revising the manuscript. Address correspondence to Wonhyuk Cho at wonhyukcho@gmail.com.
} 
perceptions and expectations of their government (Abramson and Primack 1980; Bouckaert and Van de Walle 2003; Fukuyama 1995; Kampen et al. 2006; Mishler and Rose 1997; Nye 1997; Peters 1999; Sullivan 1965). Yet, in the current climate of rapid developments to information and communications technology (ICT), as well as massive push by governments around the globe to incorporate ICT into their repertoire of tools used for governance (Brewer, Neubauer, and Geiselhart 2006; Chadwick and May 2003; Morgeson, VanAmburg, and Mithas 2011; Welch, Hinnant, and Jae Moon 2005), it is interesting to note that very little research has attempted to assess how citizens' use of the Internet affects citizens' trust in government. ${ }^{1}$

Further, as existing literature has also suggested that trust in government functions as a prerequisite to citizen compliance (Braithwaite and Makkai 1994; Lee 2003) it is likely that if the Internet bears an influence upon citizens' trust in government, that influence is likely to extend to citizen compliance as well (Braithwaite and Makkai 1994). Consequently, investigating the relationship between citizens' Internet use, citizen trust in government, and citizen compliance is of great importance to the field of Public Administration in particular and government competitiveness more generally as the world progressively moves into a digital era.

Finally, given the advancement of the Internet and society's increased dependence upon it as a means of self-expression and information procurement (Brewer, Neubauer, and Geiselhart 2006), the Internet's relevance to government will also dramatically increase as traditional forms of mass media are no longer the only tools of political communication with the public (Kettl 2000). Therefore, understanding the implications of citizens' use of this new technology again highlights the particular relevance of such research to the field of Public Administration and also speaks indirectly to broader issues regarding the state's ability to maintain its legitimacy and enhance its international competitiveness in an environment where state services and processes are progressively migrating to online formats.

Accordingly, this article attempts an initial investigation into how changes to the way information is spread, which are stimulated by the proliferation of the Internet, serve to impact citizen trust in government and citizen compliance compared with 'old media' (i.e., newspapers) and how such effects may be influenced by citizens' use of e-government. We begin our assessment of these issues by first addressing links that previous literature has found to exist between information and public (citizen trust in government) attitudes and behavior (compliance).

\section{THE IMPACT OF INFORMATION ON CITIZEN BEHAVIOR}

The main argument of this research is that citizens' use of the Internet affects citizens' trust in government and compliance. Implicit in this assertion is the assumption that information influences behavior (compliance) and attitudes/dispositions

1 Although articles such those by West (2004), Welch, Hinnant, and Jae Moon (2005), or Morgeson, VanAmburg, and Mithas (2011) represent attempts to understand how e-government use affects citizen trust in government, these articles assess how government use of the Internet affects citizens' trust in government. Our research is distinct from theirs as we assess how citizens' use of the Internet affects their trust in government and compliance. 
(trust) (cf. Lee 2003; Van de Walle and Bouckaert 2003). Such an assumption finds a great deal of support from the field of economics and agency theory, which posits that actors seek to minimize information asymmetries by acquiring new information so as to enhance their decision making capacity (Akerlof 1970; Stiglitz 2000; Thomas 1998). Accordingly, the accumulation of information serves as a source of "self-empowerment" for actors (Brainard 2003); the more information an actor possesses the less "bounded" they are in their (perceived) capacity to pursue decisions with the greatest payoffs (cf. Simon 1957).

Given the unique information environment that has been brought on by the rapid expansion and sophistication of the Internet in recent years, it is important to investigate whether, or how, the influence of information on behavior is changing (Cappella and Jamieson 1996), and what the implications of such a change are for government (Porumbescu et al. 2012).

To this end, the Internet plays an important role in influencing citizens' behavior as it serves as a mechanism that facilitates the dissemination and consumption of information. Noting the changing patterns of information dissemination brought about by new technologies such as the Internet, Mathews (1997) has argued that such information trends serve to eliminate the state's "monopoly on the collection and management of large amounts of information," which consequently "multiplies the number of players who matter and reduces the number who command great authority." As a result, a decentralization of social hierarchies occurs, which then corresponds to a reduction of the states' authority. Empirical research by Brainard (2003) has also found similar results, as she found that amassment of information by members of online communities corresponded to a greater sense of self-empowerment and ultimately reduced deference to authority.

Thus, unlike in the past, where the spread of information was constrained due to various media and political elites who performed gate keeping functions with regard to the quantity and content of disseminated information, such safeguards are apparently diminishing, which in turn is generating a waxing of non-state actor power (Kettl 2000; Mathews 1997). Indeed, the use of the Internet to disseminate information was so critical in determining the outcomes of the Egyptian revolution that it led Wael Ghonim to claim during a CNN interview regarding the 2011 Egyptian Revolution, "This revolution started online. . I've always said that if you want to liberate a society just give them the Internet."

Given such transformative changes, understanding the implications of this radically new information environment on the behavior of citizens is essential to the effective functioning of public administration in this dawning digital era.

However, before going further, it is important for this research to explain what is meant in regard to the Internet given that the term Internet becomes increasingly vague as this technology grows in sophistication and diffusion. Therefore, throughout the course of this research, we will refer to the Internet as an (generally) open, interconnected, global electronic network used facilitate citizen interaction (cf. Bimber 1998) as well as the spread and consumption of information of various sorts (DiMaggio

2 Wael Ghonim is an Internet activist who was imprisoned by the Mubarak regime for his political activism. He seen by some as the symbol of the Egyptian revolution. 
et al. 2001). Accordingly, we consider time spent on the Internet as hours per day spent by citizens engaging such electronic networks for the acquisition of information or interacting with others via devices offering such access, be they smart phones, laptops, or desktop computers.

Furthermore, as stated earlier, the intent of this research is to assess how citizens' use of the Internet affects their levels of trust in government and compliance. As a means of pursuing this research objective, we focus primarily upon the way in which the Internet is said to transform existing information environments. Accordingly, we turn to previous literature explaining the impact of the Internet upon media, which citizens have traditionally used as a means of informing themselves, and is thereby largely responsible for establishing the overall tone of information environments in society. Given the important role media has in informing citizen decisions, the media's relationship to public opinion and citizen behavior is also well studied (Moy et al. 1999; Noelle-Nuemann 1993; Norris 1996; Putnam 1995; Uslaner 1998).

Due to the open nature of the Internet relative to other forms of media, as well as its real-time, one-to-one, one-to-many, and interactive communication capacities, it is feasible for this new technology to displace or at least alter existing information environments and dissemination arrangements (DiMaggio et al. 2001; Scott 2006) that were largely influenced by what is now referred to as the "old" media. As such, citizens' use of Internet mediated "new" media is, in turn, likely to impact public opinion (trust in government) and behavior (compliance) in ways different from previous eras of media.

\section{THE NEW MEDIA ENVIRONMENT}

The proliferation of online media outlets has caused a paradigm shift in media and effectively altered the information environment in which political elites and interested citizens function (Woodly 2008). Indeed, the role of the media has been altered in many respects and was forced to adjust to the enhanced importance of informal online media outlets, such as contributors to online media, or online web loggers (hereafter bloggers), which have emerged as an important influence on agenda setting for both the media and the government (Farrell and Drezner 2008; Wallsten 2007). To this extent, if the tone of government related information dissemination by the media can be characterized as a top-down, elite-driven process that is closely correlated to the societal status quo and corresponding obligations (Woodly 2008), it appears that the intent of the online media community is to do nothing other than to shake things up a bit.

Addressing what these authors believe to be the root of the constraints placed upon traditional forms of mass media, Woodly (2008) argues that the spread of information is biased toward an elite opinion due to the rigid parameters which the "old media" must follow. Establishing a basis for this point, Entman (2004) draws on a cascading network activation model of political communication that emphasizes the importance of sequence and hierarchy, with decisions related to what is worth talking about being made by the top of the "cascade" (elites), in order to establish a framework from which the lower tiers of the "cascade" can work within. 
In light of the above, the implication of this new media environment for citizen trust in government and citizen compliance, in a general sense, is that existing status quos regarding the dissemination of information will be altered with the emergence of new non-state actors (Mathews 1997). Additionally, as these new actors serve to erode the control of traditional media elites (Woodly 2009), who served to assure that the "wrong" information does not make it "public" (Entman 2004), a further implication of the waxing of the Internet as a medium for information dissemination is that public opinion and citizen compliance are likely to be negatively affected, as the Internet facilitates the spread of all types of information, be it "right," "wrong," erroneous, or factual. Thus, given the lack of filtering, citizens are likely to be given access to much more information, which according to the arguments of Brainard (2003) is likely to encourage citizens' sense of empowerment, and subsequently makes them less willing to defer to the authority of government. ${ }^{3}$

\section{THE KOREAN CONTEXT}

It is not surprising that the government of South Korea, a nation well known for its advanced and diffuse ICT infrastructure, has aggressively pursued a greater online presence, to the extent that it now ranks first in e-government development, as well as in e-participation (Macintosh 2004). The ultimate goal of the South Korean government's e-government program was to "realize the World's best open government," and that strategy has begun to pay off.

For nations where ICT is well developed and deeply diffused, such as South Korea, the impact of the Internet on citizens' trust in government or citizen compliance can be expected to be particularly significant due to the important role new information plays in shaping citizens opinions and behavior (Bouckaert and Van de Walle 2003; Hermes 2006; Tolbert and McNeal 2003), regardless of whether that information comes from the government or non-state actors. For this reason, it is important to assess the effects of not only governments' use of ICT and the Internet, but citizens' as well.

However, while South Korea possesses among the most advanced ICT and e-government services in the world (OECD 2010; United Nations 2010), this nation also possesses a very young democracy, with its democratic transition beginning in the late 1980s (Hahm 2008) and reaching fully developed status less than 20 years later (ECI 2008).

These changes to the South Korean political and economic context have subsequently resulted in changes to the relationships between citizens and their government. Empirical research by Lee (2003) suggests that these changes to the relationships between South Korean citizens and their government have fostered strong libertarian values among citizens, which in turn have resulted in younger

\footnotetext{
3 An alternative explanation for this point comes from Noelle-Nuemann (1993) who, in her "spiral of silence" theory, argued that individual citizens, afraid of social reprisal, make efforts to stay within the confines of their perception of public opinion, with this (perceived) broad perimeter of public opinion being conveyed to citizens via mass media. However, for the sake of brevity we are unable to discuss this point in greater detail.
} 
generations of wealthier and better educated South Koreans being socialized into climates of low trust in government and political cynicism, which then serve to reduce levels of citizen compliance. Based on these empirical findings, Lee (2003) continues to argue that the situation in South Korea is not unlike that of other advanced industrialized nations where noncompliant attitudes are widespread among younger and better educated members of society (cf. Inglehart 1997; Kim 2010). To this extent, it is interesting to investigate how citizens' use of the Internet interacts with such broad trends, and whether the governments' efforts to develop e-government are moderating the aforementioned changes to relationships between citizens and their government.

Performing this vein of research within a South Korean context subsequently provides meaningful implications for developed nations that face waning levels citizen trust in government and compliance and seek to offset such trends through the use of e-government (Inglehart 1997; Morgeson, VanAmburg, and Mithas 2011). In addition, this research offers meaningful implications for less developed nations that are coming of age democratically during the age of the Internet, where relationships between citizens and their government are evermore mediated by the Internet (Dunleavy et al. 2006).

\section{TRUST IN GOVERNMENT}

When evaluating the efficiency with which a government implements its policies, trust in government represents a factor of great importance due to the fact that democratic systems rely on citizens' trust to operate effectively, as well as to stave off political apathy (Grimes 2006; Lee 2003; Nye 1997). In this context, trust may be considered to occupy a key role in making governments operate correctly (Fukuyama 1995).

Rotter (1967) defines trust as, "An expectancy held by an individual or a group that the word, promise, or verbal or written statement of another individual or group can be relied upon."4 However, definitions of trust are generally diverse, as trust is not an easily defined concept that scholars readily agree upon (Bouckaert and Van de Walle 2003; Job 2005; Kim 2005). As Uslaner (2002, 2008) explains, trust is a term that means several different things, with different contexts helping to create different types of trust. The studies on trust in government tend to support this assertion by relating notions of trust in government to issues ranging from civic engagement (Putnam 1995; Uslaner and Brown 2005), to government performance (Vigoda-Gadot and Yuval 2003; Yang and Holzer 2006), to government public relations and e-government (Tolbert and Mossberger 2006; Welch, Hinnant, and Jae Moon 2005). The factors associated with why we trust, whom we trust, and consequences of trust mentioned in these works are all necessarily inconsistent due to, as previously mentioned, the very contextual nature of trust. For this reason, scholars tend to group trust in government into various categories (Thomas 1998), but typically agree that citizens' trust in government is a function of their policy expectations and/or preferences being satisfied

4 We have chosen to use this definition as it is sufficiently broad to account for many of the diverse concepts other experts on the topic have deemed defining elements; for a thorough discussion, see Kim (2005). 
(Bouckaert and Van de Walle 2003; Christensen and Laegeid 2005; Job 2005; Van Ryzin 2004; Yang and Holzer 2006). ${ }^{5}$

Yet, despite little agreement among authors pertaining to definitions of citizen trust in government or to how trust is gained and lost, most writers agree that it is an important component of public action and cooperation (Kim 2005; Ruscio 1996; Thomas 1998). Nye (1997) flags four factors in particular which he argues are "more immediate" and "affect views toward government": the public's appraisal of government performance, the public's ideological views on certain policies, the public's assessment of ethics and integrity of people and processes of government, and the denunciation of government by political leaders and by the press. Similarly, Orren (1997), as well as Christensen and Laegeid (2005) found that the citizens' degree of trust in government is influenced by levels of satisfaction with the government performance, which serves as a logical extension of the factors that were laid out by Nye (1997). Thus, it is often assumed that a decline of trust in government may be, at least in part, tied to lower levels of citizen satisfaction (Bouckaert and Van de Walle 2003; Kampen et al. 2006; Orren 1997), and that lower levels of satisfaction are related to poor government performance (Nye 1997; Van Ryzin 2007; Welch, Hinnant, and Jae Moon 2005). The fact that citizen satisfaction and government performance appear to heavily influence public trust in government is also discussed by Vigoda-Gadot and Yuval (2003), who make the argument that strong government performance causes higher levels of public trust. They go on to explain that reforms such as New Public Management are effective in building trust because they directly address performance-related organizational features, which in turn serve to enhance efficiency and effectiveness; according to them, higher performance causes higher trust.

However, a critical evaluation of such arguments finds that the important factor of public perception of the government performance, which interplays with the actual performance and trust in government (Van de Walle and Bouckaert 2003), is not addressed sufficiently. The distinction between the subjective perception of performance and actual objective performance can clearly be attributed to subjectivity or biases of the perceiver and is important because quite often the perceptions do not reflect reality accurately (cf. Kampen et al. 2006).

Providing an interesting take on such arguments is work by Rainey (1997), which revealed that public perceptions of government are often based on incorrect information. Taking these ideas together, we are able to establish an understanding of how incorrect or misleading information can serve to reinforce preexisting biased perceptions of a government's performance.

A final point here is that, given the various dimensions of citizens' trust in government (Job 2005), it is often difficult for researchers not to confound the concept of citizens' trust in government with similar terms such as confidence or trustworthiness (Kim 2005). To this extent, researchers' ability to differentiate citizens' trust in

5 The task of delineating trust in government from other concepts such as 'confidence in government' or 'trustworthiness of government' is not a simple one. To this extent, it is difficult to know whether the measures one employs to measure 'trust in government' are actually measuring 'trust in government' and not some other related concept, such as 'confidence in government'. One way of ensuring that one is measuring trust in government and not a related concept would be to include additional and varied indicators of trust capable of assessing this concepts' various dimensions. 
government from similar concepts is a function of the data they use; the more measures the better, as this would allow the sub dimensions of trust to be better captured. As such, future research using primary data to specifically address such relationships may offer a more robust assessment of how citizen trust in government is influenced by Internet use.

In consideration of the discussion until now, we infer that the government's loss of control/influence over media outlets, which has been primarily triggered by the proliferation of the Internet (Kettl 2000; Mathews 1997; Woodly 2008), has stimulated changes to existing information environments. As previous literature, tacitly acknowledging these changes, fails to address the implications regarding citizens' trust in government, this research extends arguments made in previous literature by predicting that increased use of the Internet will correspond to lower levels of trust in government.

H1: Individuals who spend more time on the internet will demonstrate lower levels of trust in government.

\section{COMPLIANCE}

Although a comprehensive definition of trust appears to be elusive, many of the implications of trust or lack thereof are not. In particular, a great deal of research tying levels of trust to compliance appears to agree that citizen compliance is largely influenced by citizens' trust in government (Braithwaite and Makkai 1994; Grimes 2006; Lee 2003; Scholz 1998). Further research has also emphasized the importance of citizens' voluntary compliance, as it has long been attributed to achieving intended policy outcomes in diverse fields of policy study (Pressman and Wildavsky 1984).

Exploring the idea of compliance, Braithwaite and Makkai (1994) divide compliance into the two categories of self-interestedness and citizenship. Based on the idea of self-interested compliance, ${ }^{6}$ maximizing personal gains while minimizing personal losses constitute citizens' motivation for complying as citizens consequently respond to rules and authorities based on this perspective (Murphy 2002); we may also consider this a rational choice model of citizen compliance. However, the inconsistencies of this explanation are best brought to light when asking why citizens do not cheat more often on their taxes, given that the benefits in doing so are moderate and the risks are low.

In response to self-interested compliance, the competing, or perhaps complementary explanation for citizen compliance, as proposed by Braithwaite and Makkai (1994), is the notion of citizenship. Following their account, the citizen is someone who respects norms of trust as an obligation of citizenship in situations where he may or may not be rationally self-interested to do so (Braithwait and Makkai 1994). Thus, a critical element to this conceptualization of citizen-based compliance is the notion that the citizen is someone who is willing to maintain his duty toward society, in so

6 Scholz (1998) refers to this as a collective action problem and argues along similar grounds except for the fact that he goes into more depth regarding the "free riding problem." 
far as they trust the direction in which society is moving (Scholz 1998). To this end, as citizens lose faith (or confidence) in the direction into which they are "steered" by their government, their willingness to accept third party decisions is negatively affected, which in turn results in lower levels of citizen compliance (Murphy 2002). As such, as citizens lose faith in the direction their government leads them, their trust will falter, which in turn is argued to trigger corresponding reductions to citizen compliance. Such a sequence of events is plausible in an atmosphere where information related to government is increasingly critical (Gordon 2000).

As such as relationship is well documented in existing literature, we formulate our second, mediating hypothesis as follows:

H2: Individuals who show lower levels of trust in government will demonstrate lower levels of citizen compliance.

\section{E-GOVERNMENT, CITIZEN SATISFACTION, AND TRUST IN GOVERNMENT}

This research has, until now, primarily explored the ways in which citizens' use of the Internet may influence levels of the public's trust in government and compliance. However, in order to create more balanced assessment of the impact of the Internet on public trust in government and compliance, it is important to account for the ways in which government use of the Internet affect public trust in government as well. In our efforts to assess the effect of government use of the Internet on citizen trust in government, we focus on e-government.

Moon and Norris (2005) define e-government as "the electronic provision of information and services by government 24 hours per day, seven days per week." This nonstop provision of information and services is subsequently seen as offering the potential to influence the administrative processes of government by enhancing their efficiency as well as affect the ways in which citizens participate in these processes (Brewer, Neubauer, and Geiselhart 2006; Chadwick and May 2003; Tolbert and Mossberger 2006; West 2004). However, research has consistently demonstrated that the use of e-government by government has primarily targeted efficiency, while placing much less emphasis upon participation (Brewer, Neubauer, and Geiselhart 2006; Chadwick and May 2003; Im et al. forthcoming; Moon and Norris 2005; West 2000). Perhaps it is for this reason that empirical research has often addressed the relationship between e-government and trust in government, by focusing upon the performance of service provision (Goldfinch, Gauld, and Herbison 2009; Morgeson, VanAmburg, and Mithas 2011; Parent et al. 2005; Tolbert and Mossberger 2006; Welch, Hinnant, and Jae Moon 2005; West 2004). ${ }^{7}$ The findings of such research have been mixed, with some suggesting a positive relationship between citizen's use of e-government and citizens' trust in government (Parent et al. 2005; Tolbert and Mossberger 2006; Welch, Hinnant, and Jae Moon 2005), others an ambiguous one (Morgeson, VanAmburg, and Mithas 2011; West 2004), while still others have suggested that citizen use of e-government may negatively impact citizens' trust in government (Goldfinch, Gauld, and Herbison 2009). Nonetheless, as West (2004) points out, it is likely that much of

7 We consider service provision to include the provision of information to citizens. 
the ambiguity regarding e-government's impact on trust in government may dissipate as e-government develops further.

A final point with regard to e-government's role in influencing trust in government is its importance not only with regard to enhancing the performance of service provision, but also serving to manage citizen expectations. Today, through e-government web sites, the government is able to transmit almost instantly, across vast distances, a great deal of information at very low cost (Brewer, Neubauer, and Geiselhart 2006). Subsequently, citizens are better able to better understand the capacity (and limitations) of their government, and consequently, why their government has chosen the course of action it did. In this sense, such increases to the provision of information via e-government web sites also serve to reduce the extent to which citizen's feel alienated from the processes of their government, thereby offering the potential to further enhance citizens' trust in government (Nye 1997; Thomas 1998; Tolbert and Mossberger 2006).

Therefore, e-government may be seen as having the ability to enhance government performance, assist in managing citizens' expectations of government performance, and help citizens feel less alienated from the processes of their government.

H3: Higher levels of e-government use will serve to moderate the otherwise negative impact of the Internet on citizens' levels of trust in government

\section{DATA AND METHODS}

This study uses data from the 2009 Knowledge Center for Public Administration and Policy (KCPAP) Survey, which was conducted by the Korea Gallup. This survey was administered to 1,213 Korean citizens, using both the proportional stratified sampling and the multistage cluster sampling methods to ensure representativeness; the sample was stratified by eight geographic areas and then the multistage cluster method was used within the eight areas. The data were collected from March 12th to 31st, 2009 by face-to-face interviews, using structured questionnaires. To ensure reliability, a verification procedure was implemented based on telephone calls to a randomly sampled pool of $30 \%$ of survey respondents, who were then asked again about several questions to which they had previously responded. Table 1 provides the description of the sample sorted by various group classifications: the sample is consistent with the key demographics of the entire Korean population.

\section{THE MODELS AND MEASURES}

The hypotheses we test attempt to assess how changes to the existing information environment brought about by Internet use impact levels citizens' trust in government and compliance, and whether such effects stimulated by Internet use may be moderated via e-government use. The hypothesized equation models trust in government and citizen compliance as a function of not only media variables, but also the political, socioeconomic, and the demographic variables as control factors as shown in Appendix. The selection of these variables was based on previous theoretical and empirical studies. 
Table 1

Representativeness of the Sample

\begin{tabular}{llcllc}
\hline Classification & & Responses (\%) & \multicolumn{2}{c}{ Classification } & Responses (\%) \\
\hline Income & Below 836 & 6 & Gender & Female & 48 \\
(USD/a month) & $837-2,950$ & 63 & & Male & 52 \\
& 2,951 more & 30 & Region & Seoul & 23 \\
Education & No response & 1 & & Gyunggi & 27 \\
(graduation) & Elementary school & 5 & & Gyungnam & 16 \\
& Middle school & 7 & & Gyungbuk & 10 \\
& High school & 49 & & Jeolla & 10 \\
Age & College & 38 & & Chungcheong & 9 \\
& 19-29 & 23 & & Kangwon & 3 \\
& $30-39$ & 26 & Jeju & 1 \\
& $40-49$ & 24 & Metropolitan & Central & 49 \\
& 50 more & 27 & status & Suburban & 42 \\
& & & & Independent & 9 \\
\hline
\end{tabular}

Internet Use $=f$ (political variables, socioeconomic variables, demographic variables)

Trust in Government $=f$ (media variables, political variables, socioeconomic variables, demographic variables)

Citizen Compliance $=f$ (media variables, trust in government, political variables, socioeconomic variables, demographic variables)

The public's trust in government, which is the dependent variable, was calculated based on the standardized questionnaires developed by the Institute for Social Research (ISR) at the University of Michigan. This questionnaire has been used by a great deal of previous research on the subject of trust in government and has been shown to ensure the consistency and stability of the results, thus allowing comparison with the existing empirical discussions found in the literature. ${ }^{8}$ We asked four questions, each with possible responses ranging from 1, "not at all," to 5, "very much." The questions are as follows: (1) Do you think that you can trust the government to do what is right?; (2) Do you think that people in government waste a lot of the money we pay in taxes?; (3) Would you say that the government is pretty much run by a few big interests looking out for themselves, as opposed to being run for the benefit of all the people?; (4) Do you think that quite a few of the people running the government are crooked? These questions fall in line with the definition of trust outlined earlier in this research.

We also included responses to questions related to what survey participants are using most on the Internet, in order to more accurately interpret the result of the impact of time on the Internet. We allowed multiple responses to items such as web

8 Although this research has focused upon broader conceptualizations of trust in government, future research may wish to employ several additional measures targeting the sub dimensions of trust in government in order to better distinguish trust in government from terms such as confidence in government. Doing so will enable such research to better distinguish between trust in government and similar concepts such as confidence in government (Kim 2005). 
surfing, online news, online shopping, online community, online gaming, searching for information about entertainment, and searching for information about sports.

We measured the citizen compliance variable with questions as follows, using the following five-scale Likert method ranging from 1, "not at all," to 5, "very much": (1) I am willing to comply with government policies even if those policies conflict with my own interest; (2) I tend to follow what government wants me to do; (3) I will not oppose government decisions to build some unpleasant facilities such as incinerating plant or crematories in my neighborhood.

In order to test the hypotheses outlined earlier, we used multiple regression based on ordinary least squares method. When we tested for the consistency and the reliability of the trust questions, the Cronbach alpha value was found to be 0.834 , which is conventionally regarded as highly consistent. We also tested for the consistency and the reliability of the government performance variable used in multiple measures, and the Cronbach alpha value was also found to be highly consistent, with a value of 0.829 . The internal consistency of citizen compliance questions was found to be not high, with the Cronbach alpha value of 0.432 although there is no agreement on the acceptable level of consistency. ${ }^{9}$ We used these citizen compliance questions above to calculate the compliance variable, because there is lack of better measures.

\section{FINDINGS}

Table 2 shows the descriptive statistics for the dependent and explanatory variables, respectively. The respondents' average time spent using the Internet is 1.598 hours per day, whereas that reading newspapers is 0.738 hours. ${ }^{10}$ Given our (large) sample of 1,213 respondents, this finding indicates a very high probability that Korean citizens, in general, spend much more time on the Internet than they do reading newspapers. Further, the standard deviation for Internet time is much higher than that of newspaper time meaning that there are more individual differences in using Internet in terms of time spent on it. As for e-government use, the mean value was 1.237 which means general public's e-government use is not that frequent because a value of 1 indicates "rarely use" in the survey scale for e-government use. Thus, it should be pointed out, however, that despite the rapidly expanding online presence of governments around the world, only a limited number of citizens actually use government web sites (Macintosh 2004), with South Korea being no exception. Even though the vast majority of citizens in developed nations use the Internet regularly throughout the course of their daily life for many other purposes, this modern concept, with great potential to positively affect public trust, is largely underutilized in public administration areas (Brewer, Neubauer, and Geiselhart 2006).

9 The three single item measures of compliance were used as the dependent variables in three separate regression models; one model per item. What was suggested by breaking the composite measure down into separate items is that one of the three items of the composite measure was measuring a different construct. Nonetheless, all of the hypothesized relationships hold in the models using the other two items.

10 We asked citizens about their time on using this media with answer form of __ Hour __ Minutes (per day, on average), and then we rescaled this into hour as a unit. 
Table 2

Summary Statistics

\begin{tabular}{lcccc}
\hline Variable & Mean & SD & Min & Max \\
\hline Trust in government & 2.570 & 0.686 & 1 & 4.8 \\
Internet time & 1.598 & 1.881 & 0 & 16 \\
Newspaper time & 0.738 & 0.843 & 0 & 6 \\
E-government use & 1.237 & 0.680 & 1 & 6 \\
Government performance & 2.367 & 0.549 & 1 & 4 \\
Political conservativeness & 3.018 & 0.789 & 1 & 5 \\
Gender & 0.480 & 0.500 & 0 & 1 \\
Education & 3.772 & 1.147 & 1 & 5 \\
Income & 5.593 & 2.530 & 1 & 10 \\
Professional & 0.012 & 0.111 & 0 & 1 \\
City/Rural & 2.405 & 0.649 & 1 & 3 \\
White collar & 0.362 & 0.481 & 0 & 1 \\
Marriage & 0.280 & 0.449 & 0 & 1 \\
Age & 40.603 & 12.508 & 19 & 77 \\
\hline
\end{tabular}

\section{Table 3}

People Use What on the Internet

\begin{tabular}{lcc}
\hline Contents Category & Number of Responses & Respondents $(\%)$ \\
\hline Web surfing & 713 & 28.58 \\
Online news & 584 & 23.41 \\
Shopping & 310 & 12.42 \\
Online community & 275 & 11.02 \\
Online game & 223 & 8.94 \\
Entertainment info & 206 & 8.25 \\
Sports info & 183 & 7.33 \\
Total & 2494 & 100.00 \\
\hline Note: The questionnaire allowed multiple responses; so, the sum of responses is larger than the number of respondents.
\end{tabular}

Table 3 exhibits what respondents use most in the course of their daily use of the Internet. We can see that "Web Surfing," which constitutes $28.58 \%$ of all responses and "online news," which comprises $23.41 \%$ of all responses, together constitute more than $50 \%$ of the total Internet use. This means that the information related to government or government performance, possibly including biased information, can be found by Internet users and spread via, for example, favorite blogs or personal web sites.

In particular, major web portal sites in South Korea, such as Naver.com and Daum.net, by virtue of design, are particularly effective in directing browsers toward following news-related links or accessing online (debate) communities such as Daum Agora, Facebook, or Twitter, which are widely used by South Korean citizens to engage in political activities and debates (Chung 2011; Shin 2011). ${ }^{11}$

11 Both of these web sites situate the online news sections of their webpage in the very center of the layout in order to attract as much attention from browsers as possible. 
Also illustrated by table 3, the "online community" category accounts for roughly $11 \%$ of total time spent on the Internet by citizens' use. Within this category are numerous politically oriented groups (Chung 2011; Shin 2011). Here, citizens can share their political views and oftentimes spread biased information and sometimes integrate themselves as a powerful political group (Chung 2011). For example, "Nosamo," the online political community that has 122,778 members with 1,603 financial supporters, played a very important role in 2002 presidential election by greatly raising younger citizens voter turnout rates, and helping former president Roh Moohyun win election. Participation in this kind of political community is very likely to affect the perception about the government and citizen behavior.

Table 4 shows the results of the multiple regressions. The results in model 1 reveal that time spent reading newspapers, education, professional, and marriage are significantly and positively related to the time spent using the Internet, whereas gender and age are negatively associated. The results of the model 2-1 and the model 2-2 indicate that the Internet use is significantly and negatively related to trust in government $(p<.05)$, suggesting that citizens who spend more time on the Internet are likely to have lower levels of trust in government, which is in agreement with the first hypothesis. On the other hand, the time spent reading newspapers does not demonstrate a significant relationship to the level of trust in government. Regarding other factors, performance and white collar professions correlate positively with the level of trust ( $p<.001$ and $p<.01$, respectively). In addition, gender influences trust $(p<.1)$, with males being less trusting toward the government.

We have included an interaction term that multiplies Internet time by e-government use. This interaction term is significantly and positively related to trust in government. This means that even if time on the Internet negatively influences the levels of trust in government, e-government use can moderate that negative impact making it less serious. As can be seen from our results, e-government can play a positive role in curbing declining trend of trust in government. This finding offers considerable implications to government policy makers and public administrators.

In model 3, trust in government is positively correlated to the citizen compliance which is also in agreement with our hypothesis. ${ }^{12}$ Therefore, levels of citizens' trust in their government are suggested to play an important factor in policy implementation by contributing higher levels of compliance. Gender and city/rural is negatively related to the citizen compliance, whereas education is positively associated.

To further analyze the meaning of length of time spent by citizens on the Internet, we conducted logit regressions with the contents categories identified by the individual responses being used as the categories that individuals use most frequently on the Internet. As presented in table 5, the Internet time variable suggests a statistically significant and positive relationship with online news, web surfing, and online community respectively. These results mean that if individual spends more time on the Internet, the individual is likely to use it for online news, web surfing, and participating in online communities, all of which can serve as catalysts for negatively affecting citizens' trust in government and subsequently fostering noncompliant attitudes with regard to

12 We tested Internet use as an independent variable and found a significant and negative coefficient, but we excluded this variable because of multicollinearity issues in model 3. 
Table 4

Multiple Regression Results

\begin{tabular}{|c|c|c|c|c|}
\hline & \multirow{2}{*}{$\frac{\text { Internet Use }}{\text { Model } 1}$} & \multicolumn{2}{|c|}{ Trust in Government } & \multirow{2}{*}{$\begin{array}{c}\begin{array}{c}\text { Citizen } \\
\text { Compliance }\end{array} \\
\text { Model } 3 \\
\end{array}$} \\
\hline & & Model 2-1 & Model 2-2 & \\
\hline Trust in government & & & & $\begin{array}{c}0.283 * * * * \\
(0.023)\end{array}$ \\
\hline \multicolumn{5}{|l|}{ Media variables } \\
\hline Internet time & & $\begin{array}{c}-0.025 * * \\
(0.012)\end{array}$ & $\begin{array}{c}-0.061 * * \\
(0.024)\end{array}$ & \\
\hline Newspaper time & $\begin{array}{c}0.597 * * * * \\
(0.058)\end{array}$ & $\begin{array}{c}0.004 \\
(0.023)\end{array}$ & $\begin{array}{c}0.003 \\
(0.023)\end{array}$ & \\
\hline E-government use & & & $\begin{array}{l}-0.060 \\
(0.037)\end{array}$ & \\
\hline Internet time $\times$ e-government use & & & $\begin{array}{l}0.029^{*} \\
(0.016)\end{array}$ & \\
\hline Government performance & & $\begin{array}{c}0.568 * * * * \\
(0.032)\end{array}$ & $\begin{array}{c}0.567 * * * * \\
(0.032)\end{array}$ & \\
\hline Political conservativeness & $\begin{array}{l}-0.025 \\
(0.061)\end{array}$ & $\begin{array}{c}0.033 \\
(0.022)\end{array}$ & $\begin{array}{c}0.033 \\
(0.022)\end{array}$ & $\begin{array}{c}7.635 \mathrm{e}-4 \\
(0.020)\end{array}$ \\
\hline \multicolumn{5}{|l|}{ Demographic variables } \\
\hline Gender & $\begin{array}{c}-0.251 * * * \\
(0.098)\end{array}$ & $\begin{array}{c}-0.067 * \\
(0.036)\end{array}$ & $\begin{array}{c}-0.061 * \\
(0.036)\end{array}$ & $\begin{array}{c}-0.079 * * \\
(0.032)\end{array}$ \\
\hline Education & $\begin{array}{l}0.117 * * \\
(0.056)\end{array}$ & $\begin{array}{l}-0.016 \\
(0.017)\end{array}$ & $\begin{array}{c}0.017 \\
(0.017)\end{array}$ & $\begin{array}{l}0.041^{*} \\
(0.015)\end{array}$ \\
\hline Income & $\begin{array}{c}0.000 \\
(0.020)\end{array}$ & $\begin{array}{c}0.012 \\
(0.007)\end{array}$ & $\begin{array}{c}0.012 \\
(0.007)\end{array}$ & $\begin{array}{c}0.009 \\
(0.007)\end{array}$ \\
\hline Professional & $\begin{array}{l}0.898 * * \\
(0.430)\end{array}$ & $\begin{array}{c}0.023 \\
(0.163)\end{array}$ & $\begin{array}{l}-0.024 \\
(0.163)\end{array}$ & $\begin{array}{c}0.127 \\
(0.147)\end{array}$ \\
\hline City/Rural & $\begin{array}{l}-0.107 \\
(0.075)\end{array}$ & $\begin{array}{l}-0.039 \\
(0.027)\end{array}$ & $\begin{array}{l}-0.039 \\
(0.027)\end{array}$ & $\begin{array}{c}-0.081 * * * \\
(0.025)\end{array}$ \\
\hline White collar & $\begin{array}{c}0.078 \\
(0.120)\end{array}$ & & & \\
\hline Marriage & $\begin{array}{c}0.777 * * * * \\
(0.141)\end{array}$ & & & \\
\hline Age & $\begin{array}{c}-0.037 * * * * \\
(0.005)\end{array}$ & & & \\
\hline Intercept & $\begin{array}{c}2.440 * * * * \\
(0.436)\end{array}$ & $\begin{array}{c}1.154 * * * \\
(0.136)\end{array}$ & $\begin{array}{c}1.224 * * * * \\
(0.143)\end{array}$ & $\begin{array}{c}2.295 * * * * \\
(0.121)\end{array}$ \\
\hline Adjusted ${ }^{R_{2}}$ & 0.261 & 0.221 & 0.222 & 0.125 \\
\hline$\underline{N}$ & 1185 & 1184 & 1184 & 1200 \\
\hline
\end{tabular}

government policies. Regarding other variables, conservativeness is negatively related to using Internet for online news meaning that more progressive people are more likely to consume online news. Age is negatively associated with using Internet for web surfing and online community, meaning that younger generations are more likely to spend their time on the Internet for these purposes. Education is positively related to online news and online community for their time on the Internet. Income is positively related 
Table 5

Logit Regression

\begin{tabular}{|c|c|c|c|}
\hline & Online News & Web Surfing & Online Community \\
\hline Internet time & $\begin{array}{c}0.363^{* * * *} \\
(0.051)\end{array}$ & $\begin{array}{c}0.304^{* * * *} \\
(0.053)\end{array}$ & $\begin{array}{c}0.166^{* * *} \\
(0.039)\end{array}$ \\
\hline Conservativeness & $\begin{array}{c}-0.178 * * \\
(0.084)\end{array}$ & $\begin{array}{l}-0.134 \\
(0.087)\end{array}$ & $\begin{array}{c}0.139 \\
(0.097)\end{array}$ \\
\hline Age & $\begin{array}{l}-0.012 \\
(0.008)\end{array}$ & $\begin{array}{c}-0.042 * * * * \\
(0.008)\end{array}$ & $\begin{array}{c}-0.052^{* * *} \\
(0.010)\end{array}$ \\
\hline Gender & $\begin{array}{l}-0.231 \\
(0.135)\end{array}$ & $\begin{array}{l}-0.127 \\
(0.139)\end{array}$ & $\begin{array}{c}0.144 \\
(0.152)\end{array}$ \\
\hline Education & $\begin{array}{c}0.366^{* * *} \\
(0.077)\end{array}$ & $\begin{array}{c}0.419 \\
(0.079)\end{array}$ & $\begin{array}{l}0.217 * * \\
(0.094)\end{array}$ \\
\hline Income & $\begin{array}{c}0.016 \\
(0.028)\end{array}$ & $\begin{array}{c}0.049 * * * \\
(0.030)\end{array}$ & $\begin{array}{l}0.055^{*} \\
(0.032)\end{array}$ \\
\hline Professional & $\begin{array}{c}0.706 \\
(0.625)\end{array}$ & $\begin{array}{l}-0.621 \\
(0.579)\end{array}$ & $\begin{array}{l}-0.472 \\
(0.720)\end{array}$ \\
\hline White Collar & $\begin{array}{c}0.628 * * * \\
(0.161)\end{array}$ & $\begin{array}{c}0.533^{* * *} \\
(0.172)\end{array}$ & $\begin{array}{c}0.291 \\
(0.184)\end{array}$ \\
\hline Marriage & $\begin{array}{l}-0.250 \\
(0.195)\end{array}$ & $\begin{array}{c}-0.776 * * \\
(0.208)\end{array}$ & $\begin{array}{c}0.168 \\
(0.210)\end{array}$ \\
\hline City/Rural & $\begin{array}{l}-0.065 \\
(0.104)\end{array}$ & $\begin{array}{c}0.097 \\
(0.108)\end{array}$ & $\begin{array}{c}-0.202 * * \\
(0.116)\end{array}$ \\
\hline Intercept & $\begin{array}{l}-0.999 \\
(0.601)\end{array}$ & $\begin{array}{l}0.055 \\
(0.617)\end{array}$ & $\begin{array}{l}-0.897 \\
(0.696)\end{array}$ \\
\hline$N$ & 1185 & 1185 & 1185 \\
\hline Pseudo- $R^{2}$ & 0.158 & 0.182 & 0.127 \\
\hline Prob $>\mathrm{chi}^{2}$ & 0.000 & 0.000 & 0.000 \\
\hline LR $\operatorname{chi}^{2}(10)$ & 260.59 & 291.53 & 163.87 \\
\hline
\end{tabular}

to web surfing and Internet community, and marriage negatively with web surfing, city/ rural negatively with online community.

In sum, the statistical test results of this research are in agreement with our suggested hypotheses: Internet use affects negatively the levels of trust in government, and trust in government is positively associated with citizen compliance; e-government use is a moderating factor, which can reduce the negative impact of the Internet on trust in government. As such, these results suggest that citizens use of the Internet detrimentally affects trust in government and ultimately to citizen compliance, as mediated by trust in government. However, our findings also suggest that citizens' use of e-government can serve to reduce the negative influence use of the Internet has on citizens' trust in government and ultimately compliance.

\section{DISCUSSION}

This research represents an initial attempt to investigate how an erosion of state control over existing information environments, due to citizens' use of the Internet, has affected levels of citizens' trust in government and compliance in South Korea. The 
results of this study's findings suggest that this erosion of state influence over existing information environments, caused by the diffusion of the Internet, has resulted in lower levels of citizen trust in government and compliance in South Korea. Therefore, what is implied by the findings of this study is that citizens' use of the Internet serves to reduce citizens' perceptions of the state's authority.

Korean society provides with a good laboratory for assessing the implications of citizens use of the Internet to disseminate information over time. For example, research by Chung (2011) traced such processes by documenting the struggles between South Korean Buddhist and environmentalist groups, and the central government over an initiative to construct a high-speed rail line through the habitat of South Korean salamanders. In his research, Chung found that these environmental groups made use of their web sites, as well as the web site of the South Korean president, to garner widespread support for their cause of halting the construction of the railroad, and "amplify risks" associated with the project to the general public. ${ }^{13}$ Indeed the results of their dedicated efforts to foster citizen discontent regarding this ostensibly obscure project online resulted in two Korean Supreme Court hearings over the constitutionality of the proposed measure, as well as more the 2 billion dollars in additional expenses.

Building upon Chung's explanation of citizens using the Internet to amplify perceived risk, a more severe manifestation of such a practice are infodemics, which may be thought of as the viral spread of (often misleading) information regarding a particular topic. As such, infodemics play a particularly important role in shaping citizens' trust in government and subsequently compliance. Illustrating these points well are the widespread protests that took place in Seoul in 2008, which were provoked by largely erroneous information regarding a beef import clause in the recently signed agreement between South Korea and the United States: essentially, spurred by reports that Mad Cow disease was prevalent in American cattle, Koreans took to the streets in protest, for more than 40 days, with police estimates of 100,000 protesters during peak nights in downtown Seoul (Choe 2008; New York Times). Not only the protest participants showed that there was widespread discontent with President Lee's administration, but more importantly, the events demonstrated the ability for an extremely large segment of South Korean society to effectively mobilize, exchange, and promulgate (misleading) information regarding Mad Cow disease via various forms of online media in no time at all. ${ }^{14}$

This viral spread of misinformation ultimately prompted President Lee to warn Parliament on July 11, 2008, that actions must be taken to prevent against such types of "infodemics" in the future, and prompting an administrative response by the Korean Government that led to the creation of the controversial Cyber Defamation Law, the new government post of chief advisor of communication, and a new government unit for online communications. Seemingly prophetic, Arnold's theory of potential

13 Chung (2011) reveals that in the months of January and February 2005, 567 messages regarding this environmental issue were posted to the president's official web site. Further, of the 27,141 total visits to the president's web site, 21,426 of them were to the 567 messages.

14 Research by Shin (2011) found that there were more than 45,000 posts on the popular online community Daum Agora expressing discontent with the beef clause of the Korean American Free Trade Agreement, whereas millions more have read these posts. 
information provides an strong explanation in its assertion that enlarging the amount of information available to the public will ultimately force political elites to "bow to the pressure of potential citizen awareness" (as cited in Chadwick and May 2003).

However, to build upon the notion of potential information, and in keeping with the arguments made throughout this research, in addition to the amount of information available to the public it is also important to consider who is providing the information. As the example of the 2008 demonstrations in Seoul illustrates, as well as the findings of this research, the consumption of information disseminated by government, via channels such as e-government, solicit different (moderating) reactions with regard to trust in government and compliance compared with information disseminated by private citizens, which was found to promote citizen distrust in government and ultimately erode citizens perceptions of government's authority.

From such a perspective, an explanation for these different effects on trust in government may be related to the degree of diversity of information available in a given environment, which stimulates the creation increasingly diverse public opinions and citizen expectations (cf. Kettl 2002). Consequently citizens' trust in their government is likely to falter (Kampen et al. 2006), thereby triggering reductions to compliance (Scholz 1998). Such an explanation finds support from the theory of hyperpluralism. In contrast to that of citizens however, the information provided by government is likely to portray a relatively unified and consistent message that serves to foster a shared sense of direction and expectations (Bouckaert and Van de Walle 2003; Ho and Ni 2004), which both contribute toward enhanced government stability (cf. Brainard 2003; Mathews 1997). As such, the important issue for Public Administration amidst this dawning of a digital era of administration, concerns adapting methods of information dissemination to account for this new (hyperpluralist) environment of greater information availability as well as numerous new actors in the information environment (Kettl 2000; Mathews 1997; Woodly 2009) so as to better coordinate and frame flows of information.

\section{IMPLICATIONS AND CONCLUDING REMARKS}

In Economy and Society, Weber (1956) wrote, "bureaucratic administration means fundamentally domination through knowledge," with the line between information and knowledge, as Stiglitz (2000) indicated, hard to distinguish. ${ }^{15}$ However, due to the rapid diffusion of the Internet throughout society, public bureaucracy's ability to continually 'dominate through knowledge' has been impaired within this new information environment (Kettl 2000). As such, it is important for research in the field of Public Administration to investigate the implications of such an impairment on the state's ability to govern (legitimacy) and explore possible remedies. This research represents an important initial attempt at such an investigation, assessing in particular how an erosion of state control over existing information environments, due to citizens' use of the Internet, has affected levels of citizens' trust in government and compliance in South Korea.

15 Given the subjective nature associated with determining just what constitutes knowledge this article focused upon information instead. 
What the findings of this study broadly suggest are that, although Weber saw control of information as a critical aspect of a bureaucracy's ability to function, the Internet renders such control less and less possible. Accordingly, a key implication of this research, as suggested by our findings, is that government legitimacy has not been successful in shifting from physical realms to cyber realms.

Indeed, attempts have been made to control citizens' use of the Internet, such as those mentioned earlier by the Lee Administration in South Korea, as it took various administrative measures to control citizens' use of the Internet. However, given the immense speed at which the Internet is developing, one must question the appropriateness of using first-order responses in the presence of second-order changes to the operating environment of the government. Rather, administrative processes and paradigms must shift to accommodate the new and transformative demands of cyber space.

\section{FUNDING}

This work was supported by a grant from the National Research Foundation of Korea (NRF-2011-330-B00195 [I00035]).

\section{APPENDIX}

Table A1

Variables and Measures

\begin{tabular}{|c|c|c|c|}
\hline Factor & Variable & Indicator & Scale \\
\hline \multirow[t]{3}{*}{ Media } & Internet & Time spent on the Internet & $\begin{array}{l}\text { Hour Minutes (per day, on } \\
\text { average) }\end{array}$ \\
\hline & Newspaper & $\begin{array}{l}\text { time spent reading } \\
\text { newspaper }\end{array}$ & $\begin{array}{l}\text { Hour_ Minutes (per day, on } \\
\text { average) }\end{array}$ \\
\hline & $\begin{array}{l}\text { E-government } \\
\text { use }\end{array}$ & $\begin{array}{l}\text { Frequency of e-government } \\
\text { use }\end{array}$ & $\begin{aligned} 5 \text { scale }(\text { Rarely use } & =1=, \text { Use } \\
\text { almost everyday } & =6)\end{aligned}$ \\
\hline \multirow[t]{2}{*}{ Political } & Conservative & $\begin{array}{l}\text { Conservative vs. progressive } \\
\text { ideology preference }\end{array}$ & $\begin{array}{l}5 \text { scale }(\text { Very progressive }=1 \\
\text { Very conservative }=5)\end{array}$ \\
\hline & $\begin{array}{l}\text { Government } \\
\text { performance }\end{array}$ & $\begin{array}{l}\text { Average assessment of } \\
\text { government performance } \\
\text { in each policy category }{ }^{16}\end{array}$ & $\begin{array}{l}5 \text { scale }(\text { Very unsuccessful }=1, \\
\text { Very successful }=5)\end{array}$ \\
\hline Socioeconomic & Income & Monthly income level & $\begin{array}{l}10 \text { scale }(0-990 \text { USD }=1, \\
>5,000 \text { USD }=10)\end{array}$ \\
\hline \multirow[t]{5}{*}{ Demographic } & Gender & Respondent's gender & Male $=0$, female $=1$ \\
\hline & Age & Respondent's age & Age (numerical value) \\
\hline & Professional & $\begin{array}{l}\text { Respondent's job as a } \\
\text { professional }\end{array}$ & $\begin{array}{l}\text { Nonprofessional }=0, \\
\text { professional }=1\end{array}$ \\
\hline & White collar & $\begin{array}{l}\text { Respondent's job as a white } \\
\text { collar }\end{array}$ & Blue $=0$, white $=1$ \\
\hline & Marriage & Respondent's marital status & Unmarried $=0$, married $=1$ \\
\hline
\end{tabular}

16 Policy categories include economic inequality, regional conflict, law and order, employment opportunity, labor-management relations, corporation regulations, North Korea policies, taxation, employment of women, fighting corruption. 


\section{REFERENCES}

Abramson, Nancy E., and Joel R. Primack. 1980. Helping the public decide: The case of radioactive waste management. Environment: Science and Policy for Sustainable Development 22:14-40.

Abramson, Paul R., and Robert Inglehart. 1995. Value change in global perspective. Ann Arbor: Univ. of Michigan Press.

Akerlof, George, A. 1970. The market for lemons: Quality uncertainty and the market mechanism. Quarterly Journal of Economics 84 (3): 488-500.

Bimber, Bruce. 1998. The Internet and political transformation: Populism, community, and accelerated pluralism. Polity 31:133-60.

Bouckaert, Geert, and Steven Van de Walle. 2003. Comparing measures of citizen trust and user satisfaction as indicators of "good governance": Difficulties in linking trust and satisfaction indicators. International Review of Administrative Sciences 69 (3): 329-43.

Brainard, Lori A. 2003. Citizen organizing in cyberspace. American Review of Public Administration 33 (4): 384- 406.

Braithwaite, John, and Toni Makkai. 1994. Trust and compliance. Policing \& Society 4 (1): 1-12.

Brewer, Gene, A., Bruce J. Neubauer, and Karin Geiselhart. 2006. Designing and implementing e-government systems: Critical implications for public administration and democracy. Administration \& Society 38 (4): 472-99.

Cappella, Joseph, and Kathleen Jamieson. 1996. News frames, political cyncism, and media cyncism. Annals of the American Academy of Political and Social Science 546:71-84.

Chadwick, Andrew, and Christopher May. 2003. Interaction between states and citizens in the age of the Internet: E-government in the United States, Britain, and the European Union. Governance: An International Journal of Policy and Administration 16:271-300.

Choe, Sang Hun. 2008. Huge protest in Seoul threatens to topple government. New York Times, Asia Pacific, June 10.

Christensen, Tom, and Per Laegried. 2005. Trust in government: The relative importance of service satisfaction, political factors, and demography. Public Performance and Management Review 28 (4): 487-511.

Chung, Ik Jae. 2011. Social amplification of risk in the Internet environment. Risk Analysis 31 (3): 1-14.

Dalton, Russel J. 2002. Citizen Politics: Public opinion and political parties in advanced industrial democracies, 3rd ed. New York, NY: Chatham House Press.

DiMaggio, Paul, Eszter Hargittai, Russel Neuman, and John Robinson. 2001. Annual Review of Sociology 27:30307-36.

Dunleavy, Patrick, Helen Margetts, Simon Bastow, and Jane Tinkler. 2006. New public management is dead-long live digital era governance. Journal of Public Administration Research and Theory 16 (3): 467-94.

ECI, E. I. U. 2010. The Economist intelligence unit's index of democracy 2010. The Economist.

Economist Intelligence Unit. 2008. The Economist Intelligence Unit's Index of Democracy 2010. London: May 2008.

Entman, Robert M. 2004. Projections of power: Framing news, public opinion, and U.S. foreign policy. Chicago, IL: Univ. of Chicago Press.

Farrell, Henry, and Daniel W. Drezner. 2008. The power and politics of blogs. Public Choice 134:15-30.

Fukuyama, Francis. 1995. Trust: Social virtues and the creation of prosperity. New York, NY: Free Press.

Gamson, William A. 1968. Power and discontent. Homewood, NJ: Dorsey Press.

Goldfinch, Shaun, Robin Gauld, and Peter Herbison. 2009. The participation divide? Political participation, trust in government, and e-government in Australia and New Zealand. Australian Journal of Public Administration 68 (3): 333-50.

Gordon, Margaret, T. 2000. Public trust in government: The US media as an agent of accountability? International Review of Administrative Sciences 66 (2): 297-310.

Grimes, Marci. 2006. Organizing consent: The role of procedural fairness in political trust and compliance. European Journal of Political Research 45 (2): 285-315.

Hahm, C. 2008. South Korea's miraculous democracy. Journal of Democracy Volume 19 (3): 128-42. 
Hermes, Joke. 2006. Citizenship in the age of the Internet. European Journal of Communication 21 (3): 295-309.

Hetherington, M. J. 1998. The political relevance of political trust. American Political Science Review 92 (4): 791-808.

Ho, Alfred T., and Anna Ya Ni. 2004. Explaining the adoption of E-government features: A case study of Iowa county treasurers' offices. American Review of Public Administration 34 (2): 164-80.

Im, Tobin, Greg Porumbescu, and Hyunkuk Lee. Forthcoming. ICT as a buffer to change: A case study of the Seoul metropolitan government's Dasan call center. Public Performance and Management Review.

Inglehart, Roger. 1997. Modernization and post-modernization: Cultural, economic, and political change in 43 societies. Princeton, NJ: Princeton Univ. Press.

Job, Jenny. 2005. How is trust in government created? It begins at home, but ends in the parliament. Australian Review of Public Affairs 6 (1): 1-23.

Kampen, Jarl K., Steven Van de Walle, and Geert Bouckaert. 2006. Assessing the relation between satisfaction with public service delivery, and trust in government: The impact of predisposition of citizens toward government. Public Performance and Management Review 29 (4): 387-404.

Kettl, Donald, F. 2000. The transformation of governance: Globalization, devolution, and the role of government. Public Administration Review 60 (6): 488-97.

Kettl, Donald, F. 2002. The transformation of governance: Public administration for the twenty-firstcentury America. Baltimore, MA: Johns Hopkins Univ. Press.

Kim, Seok Eun. 2005. The role of trust in the modern administrative state: An integrative model. Administration \& Society 37 (5): 611-35.

Kim, Soonhee. 2010. Public trust in government in Japan and South Korea: Does the rise of critical citizens matter? Public Administration Review 70 (5): 801-10.

Lee, Aie Rie. 2003. Down and down we go: Trust and compliance in South Korea. Social Science Quarterly 84 (2): 329-43.

Luhman, Niklas. 2000. Familiarity, confidence, trust: problems and alternatives. In Trust: Making and breaking cooperative relations, ed. D. Gambetta, 94-107. Oxford, UK: Oxford Univ. Press.

Macintosh, Ann. 2004. Characterizing E-participation in policy-making. In Proceedings of the Thirty-Seventh Annual Hawaii International Conference on System Sciences, HI.

Mathews, Jessica T. 1997. Power shift. Foreign Affairs 76 (1): 50-66.

Mishler, William, and Richard Rose. 1997. Trust, distrust and skepticism: Popular evaluations of civil and political institutions in post-communist societies. Journal of Politics 59 (2): 418-51.

Moon, Myung-jae, and Donald Norris. 2005. Does managerial orientation matter? The adoption of reinventing government and e-government at the municipal level. Information Systems Journal 15 (1): 43-60.

Morgeson, Forrest V., David VanAmburg, and Sunil Mithas. 2011. Misplaced trust? Exploring the structure of the e-government-citizen trust relationship. Journal of Public Administration Research and Theory 21:257-83.

Moy, Patricia, Dietram Sheufele, and Lance Holbert. 1999. Television use and social capital: Testing Putnam's time displacement hypothesis. Mass Communication and Society 2 (1-2): 27-45.

Muller, Edward N., Thomas O. Jukam, and Mitchell A. Seligson. 1982. Diffuse political support and anti-system political behavior. American Journal of Political Science 26:240-64.

Murphy, Kristina. 2002. Procedural justice and the Australian Taxation Office: A study of scheme investors. Centre for Tax System Integrity, Research School of Social Sciences, Australia National University, Working Paper No. 35.

Nevitte, Neil. 2002. Nouvelles valeurs et gouvernance au Canada. Montréal, Canada: Les Presses de l'Université de Montréal.

Noelle-Nuemann, Elisabeth. 1993. The spiral of science: Public opinion-our social skin. Chicago, IL: University of Chicago Press.

Norris, Pippa. 1996. Does television erode social capital? A reply to Putnam. PS: Political Science and Politics 29 (3): 474-80. 
Nye, Joseph, Jr. 1997. Introduction: The decline of confidence in government. In Why people don't trust government, ed. J. Nye Jr., P. Zelikow, and D. King, 1-18. Cambridge, MA: Harvard Univ. Press.

OECD. 2010. Households with access to the Internet in selected OECD countries. OECD Key Indicators for 2010.

Orren, Gary. 1997. Fall from grace: The public's loss of faith in government. In Why people don't trust government, ed. J. Nye Jr., P. Zelikow, and D. King, 77-108. Cambridge, MA: Harvard Univ. Press.

Parent, Michael, Christine Vandebeek, and Andrew Gemino. 2005. Building trust through e-government. Government Information Quarterly 22 (4): 720-36.

Peters, B. Guy. 1999. American public policy: Promise and performance, 5th ed. New York, NY: Chatham House Publishers.

Porumbescu, Greg, Catalin Vrabie, Jiho Ahn, and Tobin Im. 2012. Factors influencing the success of participatory e-government applications in Romania and South Korea. Korean Journal of Policy Studies 27 (1): 1-21.

Pressman, Jeffrey, and Aaron Wildavsky. 1984. Implementation: How great expectations in Washington are dashed in Oakland. Berkeley: Univ. of California Press.

Putnam, Robert D. 1995. Tuning in, tuning out: The strange disappearance of social capital in America. PS: Political Science \& Politics 28 (4): 664-83.

Rainey, Hal. 1997. Understanding and managing public organizations, 2nd ed. San Francisco, CA: Jossey-Bass Publishers.

Rotter, Julian. 1967. A new scale for the measurement of interpersonal trust. Journal of Personality 35 (4): 651-65.

Ruscio, Kenneth P. 1996. Trust, democracy, and public management: A theoretical argument. Journal of Public Administration Research and Theory 6 (3): 461-77.

Scholz, John T. 1998. Trust, taxes, and compliance. In Trust and governance, ed. V. Braithwaite and M. Levi, 135-66. New York, NY: Russell Sage Foundation.

Scott, James, K. 2006. "E" the people: Do U.S. municipal government websites support public involvement? Public Administration Review, 66 (3): 341-353.

Shin, Nayoon. 2011. Candle protest in Korea and collective memory. Doctoral diss. Seoul National Univ.

Simon, Herbert, A. 1957. Models of Man: Social and Rational. Oxford, UK: Wiley.

Stanley, J. Woody, and Christopher Weare. 2004. The effects of internet use on political participation: Evidence from and agency online discussion forum. Administration \& Society 36 (5):502-27.

Stiglitz, Jeffrey. 2000. Capital market liberalization, economic growth, and instability. World Development 28 (6): 1075-86.

Sullivan, Albert. 1965. Values of public relations. In Information, influence, \& communication: A reader in public relations, ed. Otto Lerbinger and Sulliva, 412-39. New York, NY: Basic Books.

Thomas, Craig W. 1998. Maintaining and restoring public trust in government agencies and their employees. Administration and Society 30 (2): 166-93.

Tolbert, Christine J., and Ramona S. McNeal. 2003. Unraveling the effects of the Internet on political participation. Political Research Quarterly 56 (175): 175-85.

Tolbert, Caroline J., and Karen Mossberger. 2006. The effects of e-government on trust and confidence in government. Public Administration Review 66 (3): 354-69.

United Nations. 2010. E-government Survey 2010: Leveraging e-government at a time of financial and economic crisis. New York, NY: UN Publishing Section.

Uslaner, Eric. 1998. Social capital, television, and the "mean world." Political Psychology 19 (3): 441-67.

. 2002. The moral foundations of trust. Cambridge, UK: Cambridge Univ. Press.

- 2008. The foundations of trust: Macro and micro. Cambridge Journal of Economics 32: 289-94.

Uslaner, Eric, and Mitchell Brown. 2005. Inequality, trust, and civic engagement. American Politics Research 33 (6): 868-94. 
Van de Walle, Steven, and Geert Bouckaert. 2003. Public service performance and trust in government: The problem of causality. International Journal of Public Administration 26 (8, 9): 891-913.

Van Ryzin, Greg G. 2004. Expectations, performance, and citizen satisfaction with urban services. Journal of Policy Analysis and Management 23 (3): 433-48.

. 2007. Pieces of a puzzle: Linking government performance, citizen satisfaction, and trust. Public Performance \& Management Review 30 (4): 521-35.

Vigoda-Gadot, Eran, and Fany Yuval. 2003. Managerial quality, administrative performance, and trust in governance revisited: A follow up study of causality. International Journal of Public Sector Management 16 (7): 502-22.

Wallsten, Kevin. 2007. Agenda setting and the blogosphere: An analysis of the relationship between mainstream media and political blogs. Review of Policy Research 24 (6): 567-87.

Weber, Max. 1956. Economy and society: A study on the integration of economic and social theory. London, UK: Routledge and Kagen Paul.

Welch, Eric W., Charles C. Hinnant, and M. Jae Moon. 2005. Citizen satisfaction with e-government and trust in government. Journal of Public Administration Research and Theory 15 (3): 371-91.

West, Darrel, M. 2000. Assessing e-government: The Internet, democracy, and service delivery by state and federal government. The Genesis Institute. Available: http://www.insidepolitics.org/ policyreports.html.

West, D. M. 2004. E-government and the transformation of service delivery and citizen attitudes. Public Administration Review 64:15-27.

Woodly, Dana. 2008. New competencies in democratic communication? Blogs, agenda setting, and political participation. Public Choice 134:109-23.

Woodly, Deva. 2009. New competencies in democratic communication? Blogs, agenda setting and political participation. Public Choice 134:109-123.

Yang, Kaifeng, and Marc Holzer. 2006. The performance-trust link: Implications for performance measurement. Public Administration Review 66 (1): 114-26. 